\title{
Physicochemical Analysis of Surface and Ground Water in Ugbomro and Iteregbi, Delta State, Nigeria
}

\section{OVONRAMWEN, OB}

\author{
Department of Chemistry, University of Benin, Benin City, Nigeria. \\ Corresponding Author Email: adebuloyeoluwaseyi@yahoo.com; Tel: +2348057746444
}

\begin{abstract}
Physicochemical analyses of surface and groundwater samples from eleven different locations in Ugbomro and Iteregbi, Delta State, Nigeria were sampled and analyzed for physicochemical parameters according to standard methods for the examination of water and wastewater. The following mean and standard deviation were obtained from the groundwater of the communities: temp $\left({ }^{\circ} \mathrm{C}\right) 22.46 \pm 0.50$ and $23.23 \pm 0.99, \mathrm{pH} 6.63 \pm 0.68$ and $6.69 \pm 0.24$, dissolved oxygen (DO) $(\mathrm{mg} / \mathrm{L}) 5.91 \pm 0.46$ and $5.73 \pm 0.46$, chemical oxygen demand $(\mathrm{COD})(\mathrm{mg} / \mathrm{L})$ $4.24 \pm 0.01$ and $4.43 \pm 0.10$, biochemical oxygen demand (BOD) $(\mathrm{mg} / \mathrm{L}) 3.51 \pm 0.38$ and $3.84 \pm 0.21$, Turbidity (NTU) $1.22 \pm 1.07$ and $3.56 \pm 0.77$, electrical conductivity $(\mathrm{EC})(\mu \mathrm{s} / \mathrm{cm}) 748.9 \pm 215.79$ and $786.67 \pm 226.77$, color (TCU) $1.22 \pm 2.12$ and $6.11 \pm 2.11$, total alkalinity $(\mathrm{TA})(\mathrm{mg} / \mathrm{L}) 6.22 \pm 7.38$ and $\left.14.11 \pm 11.19, \mathrm{HCO}_{3^{-}}{ }^{-} \mathrm{mg} / \mathrm{L}\right) 6.22$ \pm 7.38 and $14.11 \pm 11.19, \mathrm{NO}_{3}{ }^{-}(\mathrm{mg} / \mathrm{L}) 1.13 \pm 0.62$ and $2.89 \pm 1.25$, total solids $(\mathrm{TS})(\mathrm{mg} / \mathrm{L}) 489.09 \pm 180.17$ and $664.95 \pm 373.37$, total suspended solids (TSS) $(\mathrm{mg} / \mathrm{L}) 32.25 \pm 24.29$ and $123.86 \pm 82.79$, total dissolved solids (TDS) $(\mathrm{mg} / \mathrm{L}) 456.78 \pm 163.73$ and $542.20 \pm 450.66, \mathrm{Cl}^{-}(\mathrm{mg} / \mathrm{L}) 21.20 \pm 3.20$ and $20.10 \pm 3.89$, total hardness $(\mathrm{TH})(\mathrm{mg} / \mathrm{L})$ $26.67 \pm 22.83$ and $46.78 \pm 36.17, \mathrm{Na}(\mathrm{mg} / \mathrm{L}) 1.26 \pm 0.06$ and $1.16 \pm 0.04, \mathrm{~K}(\mathrm{mg} / \mathrm{L}) 0.04 \pm 0.01$ and $0.06 \pm 0.03, \mathrm{Mg}$ $(\mathrm{mg} / \mathrm{L}) 4.32 \pm 3.23$ and $6.96 \pm 5.49, \mathrm{Ca}(\mathrm{mg} / \mathrm{L}) 8.68 \pm 9.35$ and $18.12 \pm 13.71$ respectively. The results obtained were subjected to statistical analysis and compared with the standard set by the Standards Organization of Nigeria (SON) and the World Health Organization (WHO) for water samples. Some of the parameters did not meet the standards, hence the need for treatment. The present physio-chemical analyses of surface and groundwater quality of the two neighboring university areas, Ugbomro and Iteregbi, were done to assess the environmental status of the environment before socio-economic impacts.
\end{abstract}

DOI: $\underline{\text { https://dx.doi.org/10.4314/jasem.v24i3.19 }}$

Copyright: Copyright $(\mathrm{C} 2020$ Ovonramwen. This is an open access article distributed under the Creative Commons Attribution License (CCL), which permits unrestricted use, distribution, and reproduction in any medium, provided the original work is properly cited.

Dates: Received: 16 November 2019; Revised: 11 January 2020; Accepted: 22 February 2020

Keywords: physicochemical, surface water, groundwater, water quality

Water is a vital component of all living organisms, makes up about $60 \%$ of the body's weight, and essential for proper body function. Water is either surface like lakes, rivers, streams, oceans, or groundwater such as boreholes and wells. Water quality is essential to life sustenance and a useful environmental determinant of health, human development, and wellbeing because it helps to predict and learn from natural processes in the environment and determine unguided anthropogenic activities on an ecosystem. Physicochemical parameters of water are used to monitor the quality of drinking water as regards the safety of human contact and for the health of ecosystems (Olukosi et al., 2016; Behailu et al., 2018). Different statistical methods are used to assess the probability of minimum and maximum values exceeding the critical values while correlation and regression analyses are also required to evaluate, monitor, and predict the concentration of impurities in water (Oyem et al., 2014; Tadesse et al., 2018). Urbanization is an overall sustainable development and growth that encompasses economic development, social development, and environmental protection (Washington, 2015) as well as the establishment of new universities and colleges. University campus is described as a small city that impacts on the local area for social and environmental transformation which are dynamic and diverse (Nunes et al., 2018) but contributed to many environmental problems like inadequate water, poor sanitation, waste disposal challenges, flooding, pollution (Thyberg and Tonjes, 2016; Aliyu and Amadu, 2017) due to rapid urbanization among others (Dindi, 2013; Li et al., 2016).

Owing to search for the present prevailing quality of surface and groundwater of two neighboring university areas, Ugbomro and Iteregbi, eleven different locations were sampled and analyzed for physicochemical parameters to estimate the environmental status of the environment before socioeconomic progress, as rapid population growth, industrial development, and economic boom on future water quality could be measured. 


\section{MATERIALS AND METHODS}

Study Area: The areas were Ugbomro and Iteregbi villages on the geological location of $5.33 .0-5.36 .0^{\circ} \mathrm{N}$, 5.49.30-5.51. $0^{\circ} \mathrm{E}$, about $11.7 \mathrm{~km}$ from Warri city in Delta state. The natural vegetation of the areas is rain and swampy forest while their main occupation is farming, fishing, and trading.

Sampling: Five surface water samples were collected by grab from the Warri River that passes Ugbomro and Iteregbi, before these areas at DSC bridge and after at Agbarho bridge. The six groundwater samples from the open wells and taps were also collected (Table 1). The samples were collected in pre-cleaned $2 \mathrm{~L}$ polyethylene kegs and carefully labeled. The samples for lead and cadmium metal were collected in precleaned Balmer bottles and acidified with nitric acid to $\mathrm{pH}<2$. The samples for COD were collected in precleaned $1 \mathrm{~L}$ Balmer bottles and acidified with sulphuric acid to $\mathrm{pH}<2$ meanwhile, BOD samples were collected in pre-cleaned BOD bottles. The water samples were stored in cooler at $4^{\circ} \mathrm{C}$ before transportation to the laboratory according to standard methods for the examination of water and wastewater (APHA 1060, 2005) in July 2012 in triplicate.

\begin{tabular}{|c|c|c|}
\hline $\mathrm{SN} / \mathrm{No}$ & Geological location & Type of water \\
\hline BB-1 & $\mathrm{N}_{05}^{0} 34^{1} 07.6 \mathrm{E} 005^{0} 49^{1} 58.1^{11}$ & Ugbomro-well \\
\hline BB-2 & $\mathrm{N}^{0} 5^{0} 34^{1} 37.7 \mathrm{E} 005^{0} 50^{1} 29.3^{11}$ & Iteregbi-well \\
\hline BB-3 & $\mathrm{N}_{05} 34^{1} 05.0 \mathrm{E} 005^{0} 50^{1} 04.4^{11}$ & Ugbomro-tap \\
\hline BB-5 & $\mathrm{N}^{0} 5^{0} 33^{1} 46.0 \mathrm{E} 005^{0} 50^{1} 09.4^{11}$ & Ugbomro-river \\
\hline BB-6 & $\mathrm{N}^{0} 5^{0} 33^{1} 45.3 \mathrm{E} 005^{0} 50^{1} 36.0^{11}$ & Ugbomro-river \\
\hline BB-7 & $\mathrm{N}^{0} 5^{0} 34^{1} 09.1 \mathrm{E} 005^{0} 50^{1} 27.8^{11}$ & Ugbomro-tap \\
\hline BB-9 & $\mathrm{N}^{0} 5^{0} 33^{1} 41.0 \mathrm{E} 005^{0} 49^{1} 14.0^{11}$ & DSC -river \\
\hline BB-11 & $\mathrm{N}^{0} 5^{0} 34^{1} 57.0 \mathrm{E} 005^{0} 50^{1} 54.1^{11}$ & Agbarho -river \\
\hline BB-12 & $\mathrm{N}^{0} 5^{0} 34^{1} 30.5 \mathrm{E} 005^{0} 50^{1} 35.5^{11}$ & Iteregbi-well \\
\hline BB-14 & $\mathrm{N}_{0} 5^{0} 34^{1} 31.5 \mathrm{E} 005^{0} 50^{1} 37.1^{11}$ & Iteregbi-tap \\
\hline BB15 & $\mathrm{N}_{0} 5^{0} 34^{1} 34.6 \mathrm{E} 005^{0} 50^{1} 43.6^{11}$ & Iteregbi-river \\
\hline
\end{tabular}

Sample analyzed: Temperature and $\mathrm{pH}$ were measured insitu using mercury thermometer and digital $\mathrm{pH}$ meter respectively.

Color and Turbidity were measured using $\mathrm{HACH}$ $\mathrm{DR} / 890$ colorimeter in line with the instrument procedure.

Odor: $50 \mathrm{ml}$ water sample was put inside a flask with stopper and agitated by circular movements for 3 seconds. Then the stopper was opened and the water was smelled at the very inlet of the flask. The result was recorded.

$E C$ and $D O$ were measured using calibrated DBK digital conductivity meter and DO meter respectively by following the manufacturer's instructions.
Sample digestion: $100 \mathrm{ml}$ water samples and $5 \mathrm{~mL}$ conc $\mathrm{HNO}_{3}$ were evaporated gently to 15 to $20 \mathrm{~mL}$ on a hot plate. $10 \mathrm{ml}$ each of conc $\mathrm{HNO}_{3}$ and $\mathrm{HCIO}_{4}$ (AR) were added to this mixture and digested on a hot plate to a clear solution. The mixture was allowed to cool. The digested samples were filtered using glass fiber filters. The filtrates were transferred to $50 \mathrm{~mL}$ volumetric flasks and then diluted to volume with distilled water (APHA 3030-H, 2005). The concentration of $\mathrm{Pb}^{2+}$ and $\mathrm{Cd}^{2+}$ were determined using Buck scientific atomic absorption spectrophotometer and read in their respective wavelength 283.3 and $228.9 \mathrm{~nm}$ of their lamp (APHA 3500-B Pb and Cd, 2005). Meanwhile, samples for $\mathrm{Na}^{+}$and $\mathrm{K}^{+}$were digested in 1:1 $\mathrm{HCl}$ as above and determined using flame atomic absorption method (APHA 3111-Na (K)-B, 2005).

$T A$ was determined using titrimetric (APHA 2320, 2005): $1.5 \mathrm{~mL}$ phenolphthalein indicator was added to the $50 \mathrm{~mL}$ sample, then with $1 \mathrm{~mL}$ mixed indicator and titrated with $0.01 \mathrm{M} \mathrm{H}_{2} \mathrm{SO}_{4}$.

$\mathrm{HCO}_{3}{ }^{-}$: Calculated from phenolphthalein alkalinity, total alkalinity, and $\mathrm{pH}$.

$\mathrm{mg} \mathrm{HCO3}^{-} / L=\frac{\mathrm{T}-5.00 \times 10 \quad(p H-10)}{1+0.94 \times 10 \quad(p H-10)} \quad 1$

Where, $\mathrm{T}=$ Total alkalinity; PA is phenolphthalein alkalinity and PA is zero for all the samples.

Chloride was measured using Mohr's argentometric method: In the $50 \mathrm{ml}$ sample, $1 \mathrm{ml}$ of potassium chromate indicator was added and titrated with 0.0141 $\mathrm{M} \mathrm{AgNO}$ solution till pinkish-yellow endpoint. The titration was also repeated using distilled water as blank (APHA 4500-B-Cl, 2005). Calculation,

$m g C l / L=\frac{(\mathrm{A}-\mathrm{B}) \mathrm{X} \mathrm{M} \mathrm{X} 35450}{\text { ml sample }} \quad 2$

Where: $A=m l$ titration for sample; $B=m l$ titration for blank; $\mathrm{M}=$ molarity of silver nitrate.

TH was measured using the titrimetric method: $50 \mathrm{ml}$ sample, $1 \mathrm{ml}$ of buffer solution $\left(\mathrm{NH}_{4} \mathrm{OH} \mathrm{n} \mathrm{NH}{ }_{4} \mathrm{Cl}\right)$ and $0.1 \mathrm{~g}$ of ferrochrome black tea was added and shaken well. The mixture was titrated against $0.008 \mathrm{M}$ EDTA (Ethylene diamine tetra-acetic acid) until the light bluish solution appeared (APHA 2340-C, 2005). Calculation,

$\mathrm{TH}(\mathrm{EDTA}), \mathrm{mg} \mathrm{CaCO3} / \mathrm{L}=\frac{\mathrm{A} \times \mathrm{B} \times 1000}{\mathrm{ml} \mathrm{sample}} \quad 3$

Where: $\mathrm{A}=\mathrm{mL}$ EDTA titrated for sample; $\mathrm{B}=\mathrm{mg}$ $\mathrm{CaCO}_{3}$ equivalent to $1.00 \mathrm{~mL}$ EDTA titrant. 
Calcium was determined using EDTA titrimetric: 50 $\mathrm{ml}$ sample, $2 \mathrm{ml}$ of $1 \mathrm{M} \mathrm{NaOH}$ solution and $0.1 \mathrm{~g}$ murexide indicator was added and mixed, the solution turned pink, immediately the flask was titrated against 0.01 M EDTA solution until the light purple solution appeared (APHA 3500-Ca B, 2005). Calculation,

$\mathrm{mg} \mathrm{Ca} / \mathrm{L}=\frac{\mathrm{AX} \mathrm{B} \mathrm{X} \mathrm{mgCa/L} 400.8}{\mathrm{ml} \mathrm{sample}}$

4

Where: $\mathrm{A}=\mathrm{mL}$ EDTA titrated for sample; $\mathrm{B}=\mathrm{mL}$ EDTA equivalent to $400.8 \mu \mathrm{g} \mathrm{Ca}$.

Magnesium: Calculated from total hardness and calcium of EDTA titrant (APHA 3500-Mg B, 2005).

$\mathrm{mg} \mathrm{Mg} / \mathrm{L}=(\mathrm{TH}$ as $\mathrm{mgCa} / \mathrm{L}-$ calcium hardness as $\mathrm{mgCa} / \mathrm{L}) \mathrm{X} 0.243$

Where, $\mathrm{TH}=$ total hardness, $\mathrm{mgCaCO}_{3} / \mathrm{L}$

$T S$ was determined using the gravimetric method: 20 $\mathrm{ml}$ homogenized was poured into dried and preweighed porcelain evaporating dish, dried at the temperature $103-105^{\circ} \mathrm{C}$, cooled in a desiccator and weighed (APHA 2540-B, 2005). Calculation,

$\mathrm{TS}, \mathrm{mg} / \mathrm{L}=\frac{(A-B) \times 1,000,000(\mathrm{~g})}{V(m L)}$

6

Where: $\mathrm{A}$ is the weight of the dish with the residue; $\mathrm{B}$ is the weight of the empty dish, $\mathrm{V}$ is the volume of the evaporated water.

TSS was determined using the gravimetric method: Dried and pre-weighed filter paper were used to filter the $10 \mathrm{~mL}$ sample until no traces of water were placed in the pre-weighed evaporating dish, dried at the temperature of $103-105^{\circ} \mathrm{C}$, cooled in a desiccator and weighed (APHA 2540-D, 2005). Calculation,

$\mathrm{TSS}, \mathrm{mg} / \mathrm{L}=\frac{(A-B) \times 1,000,000(\mathrm{~g})}{V(m L)}$

Where: A is the weight of the dish and filter paper with the residue; $\mathrm{B}$ is the weight of the empty dish and filter paper; $\mathrm{V}$ is the volume of the evaporated water.

TDS: $20 \mathrm{ml}$ homogenized filtrate was poured into dried and pre-weighed porcelain evaporating dish, dried at the temperature $103-105^{\circ} \mathrm{C}$, cooled in a desiccator and weighed (APHA 2540-C, 2005) but was determined by subtraction from TS and TSS.
$C O D$ was determined using open reflux: $50.0 \mathrm{~mL}$ sample or distilled water (blank), $1 \mathrm{~g} \mathrm{HgSO}_{4}$, and 5.0 $\mathrm{mL}$ conc $\mathrm{H}_{2} \mathrm{SO}_{4}$ were slowly added and dissolved in a reflux flask. To the dissolved solution, was $25.0 \mathrm{~mL}$ $\mathrm{K}_{2} \mathrm{Cr}_{2} \mathrm{O}_{7}(0.00417 \mathrm{M})$ added, cooled, and then slowly added $75 \mathrm{~mL} \mathrm{H}_{2} \mathrm{SO}_{4}-\mathrm{HgSO}_{4}$ solution, mixed, heated at reflux for $2 \mathrm{~h}$ and cooled. The cooled solution was diluted with $350 \mathrm{ml}$ distilled water and then cooled to room temperature. Excess $\mathrm{K}_{2} \mathrm{Cr}_{2} \mathrm{O}_{7}$ in it determined by titrating with $0.25 \mathrm{M}$ ferrous ammonium sulfate (FAS) using ferroin indicator. Also, the procedure was repeated with distilled as a blank (APHA 5220-B, 2005).

$\mathrm{COD}, \mathrm{mg} / \mathrm{L}=\frac{(A-B) \times M \times 8000}{\text { vol of the sample }(m L)}$

Where: $\mathrm{A}=\mathrm{mL}$ of FAS used for the blank; $\mathrm{B}=\mathrm{mL}$ of FAS used for the sample; $\mathrm{M}=$ the molarity of the FAS. $B O D$ was determined using dilution method: $300 \mathrm{~mL}$ sample water and dilution water at 1:1 were poured in $1 \mathrm{~L}$ beaker and $1 \mathrm{~mL}$ each of the reagents; phosphate buffer, $\mathrm{MgSO}_{4}, \mathrm{CaCl}_{2}, \mathrm{FeCl}_{3}, \mathrm{Na}_{2} \mathrm{SO}_{3}$ and $\mathrm{NH}_{4} \mathrm{Cl}$ were added and mixed thoroughly. $300 \mathrm{~mL}$ BOD bottle was filled with this mixture and cork with stopper without trapping air bubbles it was labelled for identification and placed in the incubator at $20^{\circ} \mathrm{C}$ for 5 -days. Another bottle was filled with the mixture and dissolved oxygen reagents $\left(2 \mathrm{ml}\right.$ each $\mathrm{MnSO}_{4}$ solution, alkaliiodide-azide reagent and concentrated sulphuric acid) by following the same procedure. DO in the water samples were measured before and after incubation ((DO ${ }_{0}$ and $\left.\mathrm{DO}_{5}\right)$ (APHA 5210-B, 2005). Calculation,

$\mathrm{BOD}, \mathrm{mg} / \mathrm{L}=\frac{(D O 2-D O 1)-(D O S 2-D O S 1)}{D} \quad 10$

Where: $\mathrm{D}=$ dilution factor; $\mathrm{DO}_{2}=\mathrm{DO}$ of sample before incubation; $\mathrm{DOA}_{1}=\mathrm{DO}$ of sample after incubation; $\mathrm{DOS}_{2}=\mathrm{DO}$ of sample blank before incubation; $\mathrm{DOS}_{1}=\mathrm{DO}$ of sample blank after incubation.

$\mathrm{NO}_{3}-\mathrm{N}$ was measured using colorimetric method: Five standards $(1,4,10,20$ and $30 \mathrm{~mL})$ from a stock solution of potassium nitrate was serially made up to $50 \mathrm{~mL}$ with distilled water and added $1 \mathrm{~mL} \mathrm{HCl}$ to each. To $50 \mathrm{~mL}$ filtered sample and $50 \mathrm{ml}$ distilled water (blank), $1 \mathrm{~mL} \mathrm{HCl}$ was added to each. The absorbance of each sample was taken at 220 and 275 $\mathrm{nm}$ for $\mathrm{NO}_{3}-\mathrm{N}$ and interference respectively and extrapolated the concentration the water samples from the calibration curve (APHA 4500- $\mathrm{NO}_{3}-\mathrm{D}, 2005$ ). 
Statistical analysis: All data generated were subjected to mean, standard deviation, and Pearson correlation coefficient using Microsoft Excel 2016.

\section{RESULTS AND DISCUSSION}

The study revealed the physicochemical parameters and mineral contents of surface and ground waters (Table 2 and 3) and the relationship in the water quality parameters (Table 4 and 5) evaluated amongst the different locations of Ugbomro and Iteregbi.

All the water samples were odor-free and acceptable for drinking expected by the SON and WHO.

The temperature of the water samples was slightly above the drinking water limit of $25^{\circ} \mathrm{C}$ (ambient) of SON and $\mathrm{WHO}$ at BB9 and BB11. There is a positive relationship between temperature and TS, TSS, BOD of the river and TS, TDS, EC, COD of groundwater. Meanwhile, there is an inverse relationship with the $\mathrm{DO}$ and $\mathrm{Cl}$ of river and groundwater respectively because the suspended particles absorb heat from sunlight needed for photosynthesis and thus reduce the concentration of DO.

Color of the water was between 0.00 and $321.50 \mathrm{TCU}$. All the groundwater fell within the drinking water permissible limit (3-15 TCU) of SON and WHO while the values of river water were above the standard. There is a positive correlation with the TA, turbidity, and $\mathrm{pH}$ but negative correlation with the EC and TDS of the river. Likewise, there is also a positive relationship with the COD, turbidity, nitrate of groundwater. Color in river water may be due to the presence of dissolved organics compounds from the decay of plant and animal matters, minerals, or chemicals such as iron and manganese in the water.

Turbidity values of the water were between 0.00 and 40.67 NTU. However, all the groundwater fell within the permissible limit (5 NTU) of SON and WHO, but the river studied was not within the range this is in line with the research of Ita that most Nigerian rivers are generally turbid with a high concentration of suspended silts particularly during the rainy season (Ita, 1985). There is a positive correlation with TA, color, $\mathrm{pH}$ but negative correlation with the EC, TDS of the river. There is also a direct relationship with color, COD, temperature, TS of the groundwater.

$E C$ of the water samples was between 126.00 in BB6 and $1490.00 \mu \mathrm{s} / \mathrm{cm}$ in BB12. All the water except BB 12 fell within $900-1000 \mu \mathrm{s} / \mathrm{cm}$ of SON and WHO guideline values for drinking water. There is a positive correlation between EC and TDS, TS, TA which indicates the presence of chemical ions in the water and gives a good idea of the concentration of impurities, mobility, and temperature of the water as stated by (Shrestha and Basnet, 2018). The $\mathrm{pH}$ values of the water sample were between 6.10 and 7.60 and fell within $6.50-8.50$ permissible limit of SON and WHO standard for drinking water. The $\mathrm{pH}$ of the river has a strong correlation with nitrate while groundwater has with DO.

The DO of the water samples varied from a minimum of 5.21 in BB9 to a maximum of $7.07 \mathrm{mg} / \mathrm{L}$ in $\mathrm{BB} 15$. The river DO increase as the river flows from BB9 due to a significant degree of self-purification along the course of the river but reduces at location BB11. The $\mathrm{pH}$, temperature, and $\mathrm{DO}$ of the river are in line with other works (Aghoghovwia, 2011; Obiyor et al., 2017).

The BOD values of the water sampled varied from 3.21 in BB6 to $4.01 \mathrm{mg} / \mathrm{L}$ in $\mathrm{BB} 11$ were considered fair and moderately clean when compared with the 3.0-4.5 mg/L (WHO, 2006). The 3.74 in BB11 was susceptible to pollution from abattoir close to the downstream point that increases the bacterial population, which lead to heavy-BOD, and also reduces the DO. There is a positive correlation between the BOD and DO of the River, indicating their dependence on each other (Okoye et al., 2014).

COD of the water samples varied from 4.17 in BB6 to $4.55 \mathrm{mg} / \mathrm{L}$ in BB12. The COD is always higher than the BOD because the COD measures substances that are both chemically and biologically oxidized. The total alkalinity values of the water samples ranged from 1.00 in BB3 to 25.67 in BB12 that fell within standard $100 \mathrm{mg} / \mathrm{L} \mathrm{SON}$ and WHO.

The TH of the water samples were between 7.67 and 89.67. All the values fell within standard $100-150$ $\mathrm{mg} / \mathrm{L}$ of SON and WHO but $81.82 \%$ of the water found soft whereas BB11 and BB12 were moderately hard within $75-150 \mathrm{mg} / \mathrm{L}$ range. There is a positive correlation between the $\mathrm{TH}$ and the TA of groundwater because of their common ions. It is also more than TA indicating the presence of noncarbonated hardness. The calcium values of the water samples ranged between 2.00 at BB7 and 33.13 $\mathrm{mg} / \mathrm{L}$ in BB11 and fell within $75 \mathrm{mg} / \mathrm{L}$ of $\mathrm{SON}$ and WHO. The magnesium values of the water samples ranged between 1.38 at $\mathrm{BB} 7$ and $13.74 \mathrm{mg} / \mathrm{L}$ in $\mathrm{BB} 11$ and fell within $20 \mathrm{mg} / \mathrm{L}$ of SON and WHO guideline. The sodium values of the water samples ranged between 1.13 and $1.33 \mathrm{mg} / \mathrm{L}$ and fell within $200 \mathrm{mg} / \mathrm{L}$ standard of SON and WHO. The potassium values of the water samples ranged between 0.03 and 0.094 was within $10 \mathrm{mg} / \mathrm{L}$ standard of SON and WHO. . 
Table 2: Physiochemical characteristics of surface and ground waters of Ugbomro and Iteregbi

\begin{tabular}{|c|c|c|c|c|c|c|c|c|c|c|c|}
\hline Parameters & BB 1 & BB 2 & BB 3 & BB 5 & BB 6 & BB 7 & BB 9 & BB 11 & BB 12 & BB 14 & BB 15 \\
\hline Temp $\left({ }^{\circ} \mathrm{C}\right)$ & $22.10 \pm 0.10$ & $22.97 \pm 0.15$ & $23.17 \pm 0.21$ & $24.17 \pm 0.15$ & $20.83 \pm 0.21$ & $22.10 \pm 0.17$ & $25.13 \pm 0.42$ & $25.40 \pm 0.46$ & $24.33 \pm 0.25$ & $22.40 \pm 0.26$ & $22.33 \pm 0.31$ \\
\hline $\mathrm{pH}$ & $7.60 \pm 0.10$ & $6.77 \pm 0.90$ & $6.20 \pm 0.10$ & $6.35 \pm 0.05$ & $6.57 \pm 0.14$ & $6.10 \pm 0.20$ & $6.50 \pm 0.05$ & $6.47 \pm 0.20$ & $6.89 \pm 0.16$ & $6.42 \pm 0.08$ & $6.60 \pm 0.00$ \\
\hline $\mathrm{DO}(\mathrm{mg} / \mathrm{L})$ & $6.51 \pm 0.01$ & $5.65 \pm 0.01$ & $5.83 \pm 0.01$ & $5.90 \pm 0.02$ & $6.93 \pm 0.01$ & $5.39 \pm 0.01$ & $5.21 \pm 0.01$ & $5.63 \pm 0.01$ & $6.23 \pm 0.01$ & $5.32 \pm 0.01$ & $7.07 \pm 0.01$ \\
\hline $\mathrm{COD}(\mathrm{mg} / \mathrm{L})$ & $4.23 \pm 0.01$ & $4.35 \pm 0.01$ & $4.23 \pm 0.01$ & $4.19 \pm 0.01$ & $4.17 \pm 0.01$ & $4.25 \pm 0.01$ & $4.40 \pm 0.01$ & $4.19 \pm 0.01$ & $4.55 \pm 0.01$ & $4.40 \pm 0.01$ & $4.47 \pm 0.01$ \\
\hline $\mathrm{BOD}(\mathrm{mg} / \mathrm{L})$ & $3.23 \pm 0.01$ & $3.84 \pm 0.00$ & $3.35 \pm 0.00$ & $3.38 \pm 0.02$ & $3.21 \pm 0.01$ & $3.94 \pm 0.02$ & $4.01 \pm 0.02$ & $3.79 \pm 0.01$ & $3.64 \pm 0.01$ & $4.06 \pm 0.01$ & $3.07 \pm 0.01$ \\
\hline Turbidity(NTU) & $1.67 \pm 0.58$ & $4.00 \pm 1.00$ & $2.00 \pm 0.00$ & $6.67 \pm 0.58$ & $40.67 \pm 1.15$ & 0.00 & $26.00 \pm 0.00$ & $29.00 \pm 3.61$ & $4.00 \pm 0.00$ & $2.67 \pm 0.58$ & $22.67 \pm 2.31$ \\
\hline $\mathrm{EC}(\mu \mathrm{s} / \mathrm{cm})$ & $915.00 \pm 1.00$ & $738.00 \pm 2.50$ & $826.70 \pm 6.10$ & $224.00 \pm 4.00$ & $126.00 \pm 2.00$ & $505.00 \pm 8.70$ & $139.30 \pm 2.30$ & $128.00 \pm 1.00$ & $1490.00 \pm 2.00$ & $132.00 \pm 1.70$ & $133.30 \pm 1.15$ \\
\hline Color (TCU) & $3.67 \pm 1.53$ & $5.67 \pm 1.15$ & 0.00 & $19.33 \pm 3.36$ & $321.33 \pm 1.53$ & 0.00 & $227.67 \pm 4.04$ & $228.33 \pm 2.52$ & $7.33 \pm 1.53$ & $7.33 \pm 1.15$ & $235.33 \pm 3.06$ \\
\hline $\mathrm{TA}(\mathrm{mg} / \mathrm{L})$ & $14.67 \pm 1.15$ & $13.33 \pm 1.53$ & $1.00 \pm 0.00$ & $2.00 \pm 1.00$ & $5.00 \pm 1.41$ & $3.00 \pm 0.00$ & $3.67 \pm 0.58$ & $4.00 \pm 0.00$ & $25.67 \pm 1.53$ & $3.33 \pm 0.58$ & $3.67 \pm 0.58$ \\
\hline $\mathrm{HCO}_{3}^{-}(\mathrm{mg} / \mathrm{L})$ & $14.67 \pm 1.15$ & $13.33 \pm 1.53$ & $1.00 \pm 0.00$ & $2.00 \pm 1.00$ & $5.00 \pm 1.41$ & $3.00 \pm 0.00$ & $3.67 \pm 0.58$ & $4.00 \pm 0.00$ & $25.67 \pm 1.53$ & $3.33 \pm 0.58$ & $3.67 \pm 0.58$ \\
\hline $\mathrm{NO}_{3}^{-}(\mathrm{mg} / \mathrm{L})$ & $1.19 \pm 0.02$ & $1.45 \pm 0.01$ & $1.71 \pm 0.01$ & $0.70 \pm 0.02$ & $2.53 \pm 0.03$ & $0.48 \pm 0.01$ & $2.23 \pm 0.02$ & $2.48 \pm 0.01$ & $3.62 \pm 0.02$ & $3.60 \pm 0.01$ & $3.29 \pm 0.00$ \\
\hline $\mathrm{TS}(\mathrm{mg} / \mathrm{L})$ & $628.33 \pm 15.17$ & $730.00 \pm 20.89$ & $553.33 \pm 11.55$ & $436.67 \pm 15.28$ & $248.60 \pm 2.88$ & $285.60 \pm 5.11$ & $496.67 \pm 15.28$ & $611.67 \pm 7.64$ & $1001.53 \pm 1.37$ & $263.33 \pm 8.35$ & $100 \pm 10.00$ \\
\hline $\mathrm{TSS}(\mathrm{mg} / \mathrm{L})$ & $31.02 \pm 5.39$ & $148.33 \pm 12.55$ & $57.13 \pm 5.51$ & $255.00 \pm 13.23$ & $145.14 \pm 2.54$ & $8.60 \pm 1.72$ & $379.67 \pm 11.68$ & $499.00 \pm 1.73$ & $31.60 \pm 8.65$ & $191.66 \pm 5.65$ & $3.87 \pm 0.67$ \\
\hline $\mathrm{TDS}(\mathrm{mg} / \mathrm{L})$ & $597.32 \pm 8.95$ & $585.00 \pm 13.23$ & $496.02 \pm 6.08$ & $181.676 \pm 7.64$ & $103.34 \pm 0.66$ & $277.00 \pm 10.82$ & $117.00 \pm 3.61$ & $112.67 \pm 6.43$ & $969.93 \pm 2.50$ & $71.67 \pm 3.21$ & $96.13 \pm 6.01$ \\
\hline $\mathrm{Cl}^{-}(\mathrm{mg} / \mathrm{L})$ & $18.08 \pm 0.35$ & $21.41 \pm 0.25$ & $21.04 \pm 0.20$ & $14.18 \pm 0.71$ & $20.39 \pm 0.76$ & $24.47 \pm 0.50$ & $12.94 \pm 1.26$ & $13.59 \pm 0.21$ & $15.72 \pm 0.20$ & $23.16 \pm 3.18$ & $70.31 \pm 2.52$ \\
\hline $\mathrm{TH}(\mathrm{mg} / \mathrm{L})$ & $52.00 \pm 3.00$ & $46.67 \pm 1.15$ & $20.33 \pm 2.52$ & $17.00 \pm 1.00$ & $14.00 \pm 0.00$ & $7.67 \pm 1.53$ & $12.00 \pm 1.00$ & $89.67 \pm 2.52$ & $83.00 \pm 1.00$ & $10.67 \pm 1.15$ & $11.33 \pm 0.33$ \\
\hline
\end{tabular}

\begin{tabular}{|c|c|c|c|c|c|c|c|c|c|c|c|}
\hline Parameters & BB1 & BB2 & BB3 & BB5 & BB6 & BB7 & BB9 & BB11 & BB12 & BB14 & BB15 \\
\hline $\mathrm{Na}(\mathrm{mg} / \mathrm{L})$ & $1.33 \pm 0.01$ & $1.20 \pm 0.02$ & $1.24 \pm 0.01$ & $1.20 \pm 0.00$ & $1.20 \pm 0.00$ & $1.22 \pm 0.00$ & $1.15 \pm 0.00$ & $1.13 \pm 0.00$ & $1.13 \pm 0.00$ & $1.15 \pm 0.01$ & $1.15 \pm 0.00$ \\
\hline $\mathrm{K}(\mathrm{mg} / \mathrm{L})$ & $0.047 \pm 0.01$ & $0.03 \pm 0.00$ & $0.04 \pm 0.00$ & $0.03 \pm 0.00$ & $0.05 \pm 0.00$ & $0.03 \pm 0.00$ & $0.04 \pm 0.01$ & $0.06 \pm 0.01$ & $0.094 \pm 0.01$ & $0.04 \pm 0.00$ & $0.03 \pm 0.00$ \\
\hline $\mathrm{Mg}(\mathrm{mg} / \mathrm{L})$ & $7.77 \pm 0.47$ & $7.35 \pm 0.20$ & $3.81 \pm 0.32$ & $2.96 \pm 0.15$ & $2.23 \pm 0.00$ & $1.38 \pm 0.37$ & $1.94 \pm 0.30$ & $13.74 \pm 0.87$ & $12.25 \pm 0.34$ & $1.29 \pm 0.31$ & $1.97 \pm 0.08$ \\
\hline $\mathrm{Ca}(\mathrm{mg} / \mathrm{L})$ & $19.37 \pm 1.29$ & $16.43 \pm 0.40$ & $4.68 \pm 1.22$ & $4.81 \pm 0.40$ & $4.81 \pm 0.00$ & $2.00 \pm 0.00$ & $4.01 \pm 0.40$ & $33.13 \pm 1.01$ & $32.60 \pm 0.47$ & $5.34 \pm 0.23$ & $3.21 \pm 0.00$ \\
\hline $\mathrm{Pb}(\mathrm{mg} / \mathrm{L})$ & $<0.001$ & $<0.001$ & $<0.001$ & $<0.001$ & $<0.001$ & $<0.001$ & $<0.001$ & $<0.001$ & $<0.001$ & $<0.001$ & $<0.001$ \\
\hline $\mathrm{Cd}(\mathrm{mg} / \mathrm{L})$ & $<0.001$ & $<0.001$ & $<0.001$ & $<0.001$ & $<0.001$ & $<0.001$ & $<0.001$ & $<0.001$ & $<0.001$ & $<0.001$ & $<0.001$ \\
\hline
\end{tabular}

Table 4: Correlation matrix of the physicochemical parameters (River water)

\begin{tabular}{|c|c|c|c|c|c|c|c|c|c|c|c|c|c|c|c|}
\hline parameters & Temp & $\mathrm{pH}$ & DO & COD & BOD & Turbidity & $\mathrm{EC}$ & color & TA & $\mathrm{NO}_{3}{ }^{-}$ & TS & TSS & TDS & $\mathrm{Cl}^{-}$ & $\mathrm{TH}$ \\
\hline Temp & 1 & & & & & & & & & & & & & & \\
\hline pH & -0.60 & 1 & & & & & & & & & & & & & \\
\hline DO & -0.92 & 0.64 & 1 & & & & & & & & & & & & \\
\hline COD & 0.03 & 0.50 & 0.36 & 1 & & & & & & & & & & & \\
\hline BOD & 0.84 & -0.35 & 0.84 & -0.02 & 1 & & & & & & & & & & \\
\hline Turbidity & -0.44 & 0.73 & 0.29 & -0.11 & 0.02 & 1 & & & & & & & & & \\
\hline $\mathrm{EC}$ & 0.23 & -0.85 & 0.23 & -0.28 & -0.10 & -0.88 & 1 & & & & & & & & \\
\hline Color & 0.45 & 0.88 & 0.36 & 0.16 & -0.03 & 0.96 & -0.96 & 1 & & & & & & & \\
\hline TA & -0.48 & 0.79 & 0.36 & -0.04 & -0.05 & 0.99 & 0.91 & 0.99 & 1 & & & & & & \\
\hline $\mathrm{NO}_{3}^{-}$ & -0.35 & 0.94 & 0.47 & 0.53 & -0.19 & 0.67 & -0.91 & 0.67 & 0.74 & 1 & & & & & \\
\hline TS & 0.85 & -0.66 & -0.91 & -0.44 & 0.86 & -0.14 & 0.17 & -0.14 & -0.22 & -0.47 & 1 & & & & \\
\hline TSS & 0.83 & -0.43 & -0.89 & -0.39 & 0.89 & -0.01 & 0.01 & -0.01 & -0.08 & -0.32 & 0.99 & 1 & & & \\
\hline TDS & 0.35 & -0.94 & -0.39 & -0.42 & 0.08 & -0.81 & 0.97 & -0.81 & -0.86 & -0.97 & 0.37 & 0.21 & 1 & & \\
\hline $\mathrm{Cl}$ & -0.46 & 0.64 & 0.72 & 0.69 & -0.67 & -0.03 & -0.26 & -0.03 & 0.08 & 0.64 & -0.83 & -0.79 & -0.46 & 1 & \\
\hline $\mathrm{TH}$ & 0.53 & -0.21 & -0.36 & -0.43 & 0.41 & 0.15 & -0.24 & 0.15 & 0.14 & 0.08 & 0.66 & 0.71 & 0.10 & 0.32 & 1 \\
\hline
\end{tabular}


Table 5: Correlation matrix of the physicochemical parameters (Groundwater)

\begin{tabular}{|c|c|c|c|c|c|c|c|c|c|c|c|c|c|c|c|}
\hline parameters & Temp & $\mathrm{pH}$ & DO & $\mathrm{COD}$ & BOD & Turbidity & $\mathrm{EC}$ & color & TA & $\mathrm{NO}_{3}^{-}$ & TS & TSS & TDS & $\mathrm{Cl}^{-}$ & $\mathrm{TH}$ \\
\hline Temp & 1 & & & & & & & & & & & & & & \\
\hline $\mathrm{pH}$ & 0.01 & 1 & & & & & & & & & & & & & \\
\hline DO & 0.31 & 0.83 & 1 & & & & & & & & & & & & \\
\hline COD & 0.74 & 0.09 & 0.05 & 1 & & & & & & & & & & & \\
\hline BOD & -0.12 & -0.54 & -0.84 & 0.37 & 1 & & & & & & & & & & \\
\hline Turbidity & 0.72 & 0.31 & 0.22 & 0.73 & 0.05 & 1 & & & & & & & & & \\
\hline $\mathrm{EC}$ & 0.76 & 0.46 & 0.78 & 0.4 & -0.57 & 0.42 & 1 & & & & & & & & \\
\hline Color & 0.39 & 0.42 & 0.11 & 0.82 & 0.33 & 0.79 & 0.13 & 1 & & & & & & & \\
\hline TA & 0.63 & 0.68 & 0.69 & 0.67 & -0.23 & 0.63 & 0.81 & 0.61 & 1 & & & & & & \\
\hline $\mathrm{NO}_{3}^{-}$ & 0.59 & 0.04 & 0.02 & 0.83 & 0.24 & 0.65 & 0.15 & 0.78 & 0.36 & 1 & & & & & \\
\hline TS & 0.81 & 0.53 & 0.71 & 0.54 & -0.44 & 0.71 & 0.93 & 0.40 & 0.88 & 0.28 & 1 & & & & \\
\hline TSS & -0.10 & -0.13 & -0.52 & 0.25 & 0.54 & 0.49 & -0.58 & 0.57 & -0.23 & 0.45 & -0.25 & 1 & & & \\
\hline TDS & 0.76 & 0.52 & 0.77 & 0.43 & -0.53 & 0.53 & 0.98 & 0.22 & 0.86 & 0.15 & 0.97 & -0.47 & 1 & & \\
\hline $\mathrm{Cl}^{-}$ & -0.66 & -0.71 & -0.89 & -0.48 & 0.61 & -0.54 & -0.89 & -0.42 & -0.87 & -0.39 & -0.89 & 0.35 & -0.89 & 1 & \\
\hline TH & 0.70 & 0.70 & 0.77 & 0.60 & -0.40 & 0.66 & 0.89 & 0.53 & 0.98 & 0.34 & 0.96 & -0.26 & -0.93 & -0.94 & 1 \\
\hline
\end{tabular}

Nitrate of the water samples ranged between 0.48 in $\mathrm{BB} 7$ and $3.62 \mathrm{mg} / \mathrm{L}$ in BB12. All the values fell within standard $10-50 \mathrm{mg} / \mathrm{L} \mathrm{SON}$ and WHO. There is a correlation with the TDS of the river. Nitrate is one of the parameters derived from human sources and inorganic fertilizers used in agriculture. Meanwhile, it can cause methemoglobinemia (blue-baby syndrome) in infants and oxidation in the body

Lead and cadmium are known as potentially harmful metals that aroused considerable concerns throughout the world. They were not detected even at instrument detecting limit which was below the standard acceptable standard indicating safety from these metals toxicity probably. Chloride of the water samples ranged between 10.64 at BB8 and $181.61 \mathrm{mg} / \mathrm{L}$ in BB13. All the values fell within standard $100-250 \mathrm{mg} / \mathrm{L}$ SON and WHO. There is a negative correlation with all other parameters of the groundwater except TSS and BOD. Chloride has been known to check the degree of sewage pollution, saltwater intrusion (Wang et al., 2019), and corrosive effect on her water systems (Cantor et al., 2003). The TS of the water samples ranged between 100.00 in BB15 and $1001.53 \mathrm{mg} / \mathrm{L}$ in BB12. It has a relationship with TSS of the river while groundwater with TDS and TH. TSS of the water samples ranged between 3.87 in BB15 and $499.00 \mathrm{mg} / \mathrm{L}$ in BB11. TDS of the water samples varied between 71.67 and $969.93 \mathrm{mg} / \mathrm{L}$. The high TDS in groundwater revealed an abundance of common ions that is due to infiltration of pollutant through dilution in subsurface soil. High TDS is associated with gastrointestinal irritation, corrosion, or incrustation.
Conclusion: The result shows the present state of the surface and groundwater in Ugbomro and Iteregbi before socio-economic progress. A comparison of the measured parameters with the national and international standards limit by SON and $\mathrm{WHO}$ guideline value for drinking water and domestic usage shows that all the parameters measured (except color, total suspended solids, total solids, and turbidity of the river) met the standards. There is an indication that the river water is polluted, therefore not suitable for drinking water and domestic uses. Hence need to be treated.

Acknowledgments: The author appreciates Prof. (Mrs) MO Edema for her supervision of this research work and $\operatorname{Dr}(\mathrm{Ms}) \mathrm{DF}$ Ogeleka for the directives to Thermosteel Nigeria Limited Environmental laboratory, Warri where some of the parameters were carried out.

\section{REFERENCES}

Aghoghovwia, AO (2011). Physico-Chemical Characteristics of Warri River in the Niger Delta Region of Nigeria. Journal of Environmental Issues and Agriculture in Developing Countries 3(2): 40-46.

Aliyu, AA; Amadu, L (2017). Urbanization, Cities, and Health: The Challenges to Nigeria - A Review. Ann. Afr. Med. 16(4): 149-158. 
APHA (2005). Standard Methods for the Examination of Water and wastewater: 1060-sampling, storage, and Preservation, 4500- $\mathrm{NO}_{3}-\mathrm{D}, 2510-\mathrm{B}$. Conductivity, 2540-B total solid, 2320-alkalinity, 2540-D TSS, 4500-Cl B, pH, 5210-B BOD, 5220 COD, 3500-Ca D, 3500-Mg B, 3500-Cd1060, 3500-Na B, 3500-B K, 2550 temperature, 2340-C Hardness, 3500-B Pb, 21st edition, Eaton, Clesceri, AD; Rice, LS; Greenberg, EW; Franson, AE; MAH. American Public Health Association: Washington, DC, USA

Behailu, TW; Badessa, TS; Tewodros, BA (2018). Analysis of physical and chemical parameters in groundwater consumed within Konso area, Southwestern Ethiopia. Afr. J. Environ. Sci. Technol. 12(3): 106-114.

Cantor, A; Park, J; Vaiyavatjamai, P (2003). Effect of chlorine on corrosion in drinking water systems. J. Am. Water Works Ass. 95(5): 112-123.

Dindi, AM (2013). The Impact of the Rapid Expansion of Universities on their Neighbourhood Development; A case Study of Jkuat Juja Campus. paper presented in the proceedings of SABS Conference on Promoting Sustainable Built Environments: Architecture, Environment, Technology and Society in the Global South, (1012 October 2013) JKUAT, AICAD Juja, Kenya., At Juja, Kenya.

Ita, EO; Omorikonba, WE; Bankole, NO; Ibitoye, B (1985). A preliminary report of as immediate post impounding fisheries survey on the newly created Jebba Lake KLRI 1983. Ann. Rep. 75-92.

Nunes, BT; Pollard, SJT; Burgess, PJ; Ellis, G; de Los Rios, IC; Charnley, F (2018). University Contributions to the Circular Economy: Professing the Hidden Curriculum. Sustainability. $10,2719$.

Obiyor, IK; Nwani, CD; Odo, GE; Madu, JC; Ndudim, DU; Aguzie, ION (2017). Benthic Fish Fauna and Physicochemical Parameters of Otamiri River, Imo State, Nigeria. Fish Aqua J. 8: 199.

Okoye, CO; Iteyere, PO (2014). Health Implications of Polluting Warri-River in Delta State, Nigeria. I. J. E. S. I. 3 (4): 35-43.
Olukosi, OM; Ameh, JB; Abdullahi, IO; Whong, CMZ (2016). Physicochemical Quality of Drinking Water from Various Water Sources of Kaduna State, Nigeria. BAJOPAS. 9(2): 141 - 144.

Oyem, HH; Oyem, IM; Ezeweali, D (2014). Temperature, $\mathrm{pH}$, Electrical Conductivity, Total Dissolved Solids and Chemical Oxygen Demand of Groundwater in Boji-Boji Agbor/Owa Area and Immediate Suburbs. Res. J. Environ. Sci. 8 (8): 444-450.

Shrestha, AK; Basnet, N (2018). The Correlation and Regression Analysis of Physicochemical Parameters of River Water for the Evaluation of Percentage Contribution to Electrical Conductivity. J of Chem. Vol 2018,

SON (2015). Nigerian Industrial Standard NIS-5542015, Nigerian Standard for Drinking Water Quality. ICS 13.060.20. Price Group C, 1-28.

Tadesse, M; Tsegaye, D; Girma, G (2018). Assessment of the level of some Physicochemical parameters and heavy metals of Rebu river in Oromia region, Ethiopia. MOJ Biol. Med. 3(4): 99-118.

Thyberg, KL; Tonjes, DJ (2016). Drivers of food waste and their implications for sustainable policy development. Resour. Conserv. Recy., 106: 110123.

Wang, M; Han, M; Hui, H; Li, Y (2019). Study on seawater intrusion in Laizhou bay coastal zone based on the groundwater model. Int. J. LowCarbon Tec. 14 (2): 222-226.

Washington DC, New York: Department of Economic and Social Affairs; (2015). United Nations: World Population Prospects: The 2014 Revision United Nations.

WHO (2006). Guideline for Drinking Water Quality. 3rd Edn. Vol. 1, Recommendations Nonserial Publication, Geneva, Switzerland, ISBN-13: 9789241546744.

WHO (2017). Guidelines for drinking-water quality. Fourth edition incorporating the first addendum. Geneva: World Health Organization. 